\title{
Protein enrichment of Irish potatoes by fermentation process using mutant isolates of Latobacillus bulgaricus
}

\author{
J. R. KUTSHIK *, S. Y. GAZUWA, S. G. MAFULUL and U. ALI-DUNKRAH \\ Department of Biochemistry, Faculty of Medical Sciences, University of Jos, P.M.B. 2084, Jos, Plateau State, \\ Nigeria. \\ *Corresponding author; E-mail: kutshik@yahoo.com,Tel: +2348059146439
}

\begin{abstract}
The study undertook the mutational selection of lactic acid bacteria used for the fermentation of peeled Solanum tuberosum (Irish Potatoes, Subtrate) in order to isolate mutants that may produce fermented Irish potatoes product with improved nutritional quality (i.e increase protein content). Lactic acid bacteria were isolated from local yoghurt ("kindirmo" in hausa language) that were morphologically and culturally characterised and found to be predominantly Lactobacillus bulgaricus. Four (4) mutants selected randomly from Lactobacillus bulgaricus subjected to UV-light irradiation at 20 secs , 25 secs, 30 secs and 35 secs periods of exposure. The mutants exhibited similar morphological and cultural characteristics as the wild type strain. Fermentation of peeled Irish potatoes with wild type Lactobacillus bulgaricus gave no significant increase $(\mathrm{P}>0.05)$ in crude protein content from $7.37 \pm 0.42 \mathrm{~g} / 100 \mathrm{~g}$ on the zero day to $8.73 \pm 0.43 \mathrm{~g} / 100 \mathrm{~g}$ on the $5^{\text {th }}$ day of fermentation, whereas, the mutant isolates gave a significant increase $(\mathrm{P}<0.05)$ of crude protein content from $7.37 \pm 0.42 \mathrm{~g} / 100 \mathrm{~g}$ (zero day of fermentation) to $11.52 \pm 0.62 \mathrm{~g} / 100 \mathrm{~g}, 12.18 \pm 0.62 \mathrm{~g} / 100 \mathrm{~g}$, $9.72 \pm 0.88 \mathrm{~g} / 100 \mathrm{~g}$ and $14.50 \pm 0.52 \mathrm{~g} / 100 \mathrm{~g}$ at $6^{\text {th }}$ day of fermentation respectively. The mutant isolates, Lb35, showed the highest crude protein content $(16.91 \pm 0.73 \mathrm{~g} / 100 \mathrm{~g})$ increase after the $5^{\text {th }}$ day of fermentation of Irish Potatoes (Solanum tuberosum). The genetic analysis revealed that the Lactobacillus bulgaricus studied did not harbour any extrachromsomal element.

(C) 2010 International Formulae Group. All rights reserved.
\end{abstract}

Keywords: Irish Potatoes, mutagenesis and selection, amino acids, plasmids, mutants, wildtype, fermentation.

\section{INTRODUCTION}

Biotechnology has been broadly defined as the utilisation of biologically derived molecules, structure, cells or organisms to carry out a specific process. This shows that the world of biology is undergoing a revolution of far-reaching implications, where microbes, plants and eukaryotic cells can be programmed to produce or overproduce normal or scarce natural products. The beauty of modern biotechnology lies in its specificity: one can target the production of an important flavour, colour or enzyme in many folds (Bruce, et al., 1988).

Irish Potatoes (Solanum tuberosum) is a perennial plant of the Solanaceae or nightshade family and is commonly grown for its starchy tuber; it is one of the world most widely grown tuber crop and the fourth largest 
crop in terms of fresh produce (after rice, wheat and maize) (Hamilton et al., 2004). Because of the nutrient contents of plant foods, today's lifestyle related disease are best prevented through dietetic therapy (South African Potatoes, 2005). Albeit the Irish potatoes proteins are lacking in essential amino acids (SAP, 2005).

Axelsson (1998) and Adams and Moss (1995) stated that "lactic acid bacteria " are a group of gram positive bacteria, non-respiring, non-sporing end product of the fermentation of carbohydrates.

Fermentation has been defined as a dynamic process during which several catabolic and anabolic reactions proceed simultaneously depending on several conditions including substrate micro flora and environmental factors, which usually result in the breakdown of carbohydrates and other nutrients to give products such as Alcohols, Acids, Amino Acids, other metabolites and antibiotics including small amount of energy (FAO, 1998. Fermented foods play important role in providing food security, enhancing livelihoods and improving the nutrition and social wellbeing of millions of people around the world. It also leads to improved food preservation, increasing the range of raw materials that can be used to produce edible food products and removing anti-nutritional factors to make food safe to eat (FAO, 1998).

Mutagenesis is the process by which DNA is experimentally altered by physiochemical means to produce a stable change in the 'Gene'. Selection is the process of finding the mutant in the sea of a million "normal" bacteria (Elander, 1982; Roland, 1984). Mutagenesis and Selection have been used to produce bacteria which excrete high concentrations of amino acids (Shiio, 1982). Some of the mutagenic tools are Site-directed mutagenesis, direct selection, environmental stress, transposons, physical tools such as Ultraviolet light and chemical agents (Williams and Michael, 2000).
Mutation provides the basis of genetic studies (Williams and Michael, 2000). This study seeks to utilise one of the mutagenic techniques for improvement of Lactobacillus spp for fermentation of Irish potatoes with possible increase in protein (amino acids).

\section{MATERIALS AND METHODS \\ Sample collection}

Lactic acid bacteria strains (Lactobacillus bulgaricus) were isolated from "kindirmo" bought from Fulani women hawking it in University of Jos, Jos, Nigeria.

\section{Isolation of lactic acid bacterial strains}

Lactic acid bacterial strains were isolated from "kindirmo" culture on a selective medium (MRS agar) for lactic acid bacteria (Oxiod, 2004), and the strain identified according to its incubation temperature $\left(30{ }^{\circ} \mathrm{C}\right)$ and growth in acidic medium. The strain was further characterised according to its morphological, cultural, physiochemical and biochemical characteristics using standard methods (refs) stock cultures were maintained at $4{ }^{\circ} \mathrm{C}$ on MRS medium for further use.

\section{Fermentation process}

The substrate was washed, peeled and mashed, $100 \mathrm{~g}$ of the mash substrate was placed into conical flask, mixed with $1 \mathrm{ml}$ of the isolated Lactobacillus bulgaricus and allowed to undergo fermentation under microaerophilic condition at $30{ }^{\circ} \mathrm{C}$ in oven for 7 days. On a daily basis, samplings of each of the 7 sets of fermented potatoes were taken to check for $\mathrm{pH}$, dried matter and proximate analysis.

\section{Induction of mutagenesis}

Mutagenesis with ultra violet (UV) light were done according to Kamal et al. (2003). 


\section{UV - mutagenesis}

Lactobacillus bulgaricus were grown at $30{ }^{\circ} \mathrm{C}$ in $100 \mathrm{ml}$ of tryptone soya broth (TSB) to cell optical density (O.D 600) of 0.2-0.3. The cells were harvested by centrifugation at $5,000 \mathrm{Xg}$ for $15 \mathrm{~min}$ and washed twice in 100 $\mathrm{ml}$ cold, sterile, $0.9 \% \mathrm{NaCl}$ solution. Portion of cell suspensions ( $8 \mathrm{ml}$ aliquots $)$ was transferred to sterile petri dishes and radiated with UV - light $(254 \mathrm{~nm})$ for four different periods $(20,25,30$ and $35 \mathrm{sec})$. Each irradiated sample was centrifuged at 5,000 X $\mathrm{g}$ for $15 \mathrm{~min}$ and re-suspended in $10 \mathrm{ml}$ TSB and incubated at $30{ }^{\circ} \mathrm{C}$ for $18 \mathrm{hr}$. The cultures were then diluted serially into sterile $0.9 \%$ $\mathrm{NaCl}$ solution and $0.1 \mathrm{ml}$ of serial dilution were plated on to MRS agar plates and incubated at $30{ }^{\circ} \mathrm{C}$. Then mutants were isolated.

\section{Characterisation of mutant isolates}

Cell morphology was performed according to Ridge (1982), catalase test according to Schieri and Blazevic (1981), physiological test was as described by Oxoid (2004) and biochemical test was as according to the methods of Harrigan and McCance (1993), Sambrook et al. (1989) and Tserovska et al. (2002).

\section{Isolation of plasmids}

Plasmid analysis was carried out using the "Simple method for extracting plasmid DNA from lactic acid bacteria" by Frere (2008).

\section{Statistical analysis}

The statistical analysis used were simple standard deviation, percentage, ANOVA and correlation at $95 \%$ level of significance.

\section{RESULTS}

Isolation and identification of lactic acid bacteria

Microscopic examination of the isolates revealed rods-like cells that showed no catalase activity; motile, facultative anaerobic, gram positive bacteria (+ve), grow best at $30{ }^{\circ} \mathrm{C}$ with a pH range of 6.3-5.4, small colony size and creamy grey in colour on MRS agar, the selective media for lactic acid bacteria (Oxoid, 2004).

\section{Biochemical test}

The mutants isolates was found to react positively with Glucose, Galactose, Fructose, Lactose, Mannitol and Inulin as demonstrated in the method of Harrigan and McCance (1993), Sambrook et al. (1989), and Rserovska et al. (2002).

The reaction of $\mathrm{Lb} 30$ and $\mathrm{Lb} 35$ is also better on mannitol and $\mathrm{Lb} 35$ is also better on inulin as compared to the wild type.

The protein content of mutants isolates Lb 20 shows a significant increase $(\mathrm{P}<0.05)$ from $7.37 \pm 0.42$ at zero day of fermentation to $11.48 \pm 0.62$ ( $5^{\text {th }}$ day of fermentation) and 11.52 ( $6^{\text {th }}$ day of fermentation). Similarly, there were significant increase $(P<0.05)$ in the crude protein content of mutants isolates $\mathrm{Lb} 25, \mathrm{Lb} 30$, and $\mathrm{Lb} 35$ from $7.3 \pm 0.42$ at zero day to $11.21 \pm 1.05,5.80 \pm 0.39$ and $11.91 \pm 0.82$ (fourth day of fermentation), $9.72 \pm 0.92,9.29 \pm 0.53$, and $16.91 \pm 0.73$ ((fifth day of fermentation) and $12.18 \pm 0.62$, $9.72 \pm 0.88$ and $14.50 \pm 0.52$ (sixth day of fermentation) respectively.

The mutants isolates Lb 35 showed the highest crude protein content increase after the fifth day of fermentation of Irish potatoes (Solanum tuberosum).

\section{Plasmid analysis}

The result of Plasmid analysis showed the complete absence of any chromosomal element in the Lactobacillus bulgaricus strain. 
Table 1: Identification of Lactobacillus bulgaricus Isolates from "kindirmo".

\begin{tabular}{lc}
\hline Characteristic & Isolate L. bulgaricus \\
\hline Growth on MRS agar ( $\mathrm{pH}$ 6.3) & $+\mathrm{ve}$ \\
Growth on MRS agar $(\mathrm{pH} 5.4)$ & $+\mathrm{ve}$ \\
Temperature of incubation & $30{ }^{\circ} \mathrm{C}$ \\
Catalase activity & $-\mathrm{ve}$ \\
Gram reaction & $+\mathrm{ve}$ \\
Cell morphology & rods \\
Colony size & small \\
Colony shape & circular, irregular \\
Colony colour & creamy grey \\
\hline
\end{tabular}

Table 2: The results for biochemical tests of Lactobacillus bulgaricus isolates from "Kindirmo".

\begin{tabular}{lc}
\hline Sugar & Reaction \\
\hline Glucose & +++ \\
Galactose & ++ \\
Frustose & +++ \\
Lactose & +++ \\
Mannitol & ++ \\
Inulin & ++ \\
\hline Key: +++ strongly positive $++=$ moderately positive + + positive.
\end{tabular}

Table 3: Characterisation of mutant isolates of Lactobacillus bulgaricus.

\begin{tabular}{lcccc}
\hline & & Mutants & Isolates L. & bulgaricus \\
\hline Characteristics & Lb 20 & Lb 25 & Lb 30 & Lb 35 \\
\hline $\begin{array}{l}\text { Growth on MRS agar } \\
\text { (pH 6.3) }\end{array}$ & $+\mathrm{ve}$ & $+\mathrm{ve}$ & $+\mathrm{ve}$ & $+\mathrm{ve}$ \\
$\begin{array}{l}\text { Growth on MRS agar } \\
\text { (pH 5.4) }\end{array}$ & $+\mathrm{ve}$ & $+\mathrm{ve}$ & $+\mathrm{ve}$ & $+\mathrm{ve}$ \\
$\begin{array}{l}\text { Temperature of Incubation } \\
\text { Catalase activity }\end{array}$ & $30{ }^{\circ} \mathrm{C}$ & $30{ }^{\circ} \mathrm{C}$ & $30{ }^{\circ} \mathrm{C}$ & $30{ }^{\circ} \mathrm{C}$ \\
Gram morphology & $-\mathrm{ve}$ & $-\mathrm{ve}$ & $-\mathrm{ve}$ & $-\mathrm{ve}$ \\
Colony size & rods & rods & rods & rods \\
Colony shape & small & small & small & small \\
Colony colour & Circular & Circular & Circular & Circular \\
\hline Key: & creamy grey & creamy grey & creamy grey & creamy grey \\
\hline
\end{tabular}

Key: +ve = positive ; -ve = negative

$\mathrm{Lb} 20=$ Lactobacillus bulgaricus exposed to UV-light for 20 seconds

Lb 25 = Lactobacillus bulgaricus exposed to UV-light for 25 seconds

Lb 30 = Lactobacillus bulgaricus exposed to UV-light for 30 seconds

$\mathrm{Lb} 35=$ Lactobacillus bulgaricus exposed to UV-light for 35 seconds

Microscopic examination of the mutant isolates revealed all the above characteristics as demonstrated by Oxoid (2004). 
Table 4: Biochemical characteristics of mutants of L. bulgaricus.

\begin{tabular}{|c|c|c|c|c|}
\hline & & Mutants & Isolates & L.bulgaricus \\
\hline Sugar & Lb 20 & Lb 25 & Lb 30 & Lb 35 \\
\hline Glucose & +++ & +++ & +++ & +++ \\
\hline Galatose & ++ & +++ & +++ & +++ \\
\hline Fructose & +++ & +++ & +++ & +++ \\
\hline Lactose & ++ & ++ & +++ & +++ \\
\hline Mannitol & +++ & +++ & +++ & +++ \\
\hline Inulin & ++ & ++ & ++ & +++ \\
\hline
\end{tabular}

Table 5: Proximate analysis of unfermented and fermented content of Irish Potatoes with wild type L. bulgaricus.

\begin{tabular}{|c|c|c|c|c|c|}
\hline & \multicolumn{5}{|c|}{ Periods in days } \\
\hline $\begin{array}{l}\text { Components of Proximate } \\
\text { Analysis }\end{array}$ & $\mathbf{0}$ & 4 & 5 & 6 & 7 \\
\hline Crude protein $(\%)$ & $7.37 \pm 0.42$ & $8.70 \pm 0.26$ & $8.73 \pm 0.43$ & $8.03 \pm 0.53$ & $7.64 \pm 0.33$ \\
\hline Crude Fibre (\%) & $5.64+0.53$ & $3.37 \overline{+} 0.41$ & $2.09+0.35$ & $2.39+0.34$ & $2.70+0.51$ \\
\hline $\operatorname{NFE}(\%)$ & $16.15+1.21$ & $14.6 \overline{3} \pm 0.45$ & $3.88 \pm 0.50$ & $5.72 \pm 0.33$ & $5.73 \pm 0.41$ \\
\hline Ash content $(\%)$ & $5.83 \overline{ \pm 0} .41$ & $11.15 \pm 0.38$ & $10.2 \overline{5 \pm 0.40}$ & $9.83 \pm 0.32$ & $10.8 \overline{8}+0.41$ \\
\hline Crude fat (\%) & $0.01 \pm \overline{ \pm 0} 0.001$ & $0.05 \pm \overline{0} .004$ & $0.05 \pm \overline{0} .004$ & $0.03 \pm 0.005$ & $0.05 \pm \overline{0} .005$ \\
\hline Moisture contents (\%) & $65.00+1.58$ & $72.00+1.43$ & $75.00+1.25$ & $74.00+0.50$ & $73.00+0.50$ \\
\hline
\end{tabular}

Table 6: Protein analysis of fermented Irish Potatoes with mutants isolates.

\begin{tabular}{lclll}
\hline Mutants isolates & \multicolumn{4}{c}{ Fermentation periods in day } \\
\hline at periods in seconds & $\mathbf{0}$ & $\mathbf{4}$ & $\mathbf{5}$ & \multicolumn{1}{c}{$\mathbf{6}$} \\
\hline Lb 20 & $7.37 \pm 0.42$ & $5.87 \pm 0.78$ & $11.48 \pm 0.51$ & $11.52 \pm 0.62$ \\
Lb 25 & $7.37 \pm 0.42$ & $11.21 \pm 1.05$ & $9.72 \pm 0.92$ & $12.18 \pm 0.62$ \\
Lb 30 & $7.30 \pm 0.42$ & $5.80 \pm 0.39$ & $9.29 \pm 0.53$ & $9.72 \pm 0.88$ \\
Lb 35 & $7.37 \pm 0.42$ & $11.91 \pm 0.82$ & $16.91 \pm 0.73$ & $14.50 \pm 0.52$ \\
\hline
\end{tabular}

Note: All readings were means of three determinations $( \pm \mathrm{SD})$. Lb $20=$ Lactobacillus bulgaricus exposed to UV-light for 20 secs; Lb 25 = Lactobacillus bulgaricus exposed to UV-light for 25 secs; Lb $30=$ Lactobacillus bulgaricus exposed to UV-light for 30 secs. Lb 35 = Lactobacillus bulgaricus exposed to UV-light for 35 secs.

\section{DISCUSSION}

One of the major objectives of this research was to develop a simple biotechnological method that can be adopted and applied to improve the nutritional quality of some staple starchy foods such as Irish potatoes (Solanum tuberosum) with protein (amino acids) as there is high demand for essential amino acids for use in foods, feeds and in the pharmaceutical industries is 
expanding (microbiology procedure.com). Research has also shown that it is genetically possible to "tailor" the microoganisms for the production of any microbial metabolitevitamins, amino acids, or enzymes.

The isolation, identification and characterisation of the lactic acid bacteria isolate showed that the bacteria species was Lactobacillus bulgaricus (Tables 1 and 2). The isolates of the wild type was found to react positively with glucose, Galactose, Fructose, Lactose, Mannitol and Inulin as demonstrated in the method of Harrigan and McCance (1993), Sambrook et al. (1989), and Rserovska et al. (2002) (Table 2). The mutant isolates also showed the same morphological and biochemical reaction similar to the wild type strains (Tables 3 and 4). The crude protein content of the fermented Irish potatoes with the wild type strain showed no considerable increase in the crude protein content from zero day to the seventh day of fermentation with a probable peak period of fermentation at the fifth day $\left(5^{\text {th }}\right.$ day) $8.73+0.43 \mathrm{~g} / 100 \mathrm{~g}$, (Table 5), whereas the mutant isolates generally showed a significant increase $(\mathrm{P}<0.05)$ in their crude protein content from zero day to the $6^{\text {th }}$ day. Mutants strains $\mathrm{Lb} 20, \mathrm{Lb} 25$, and $\mathrm{Lb} 30$ shows a peak crude protein content at the $6^{\text {th }}$ day of fermentation $(11.52+0.62,12.18+0.62$, and 9.72+0.88) and mutant strain Lb 35 shows its peak crude protein content at the $5^{\text {th }}$ day $(16.91+0.73)$ respectively. The peak period of fermentation for the mutant isolates could not be determined by these results as the fermentation has not exceeded the $6^{\text {th }}$ day as it was in the case with wild type strain (Table 6).

The increase in crude protein content observed in the mutants isolate might probably be due to increase in conversion of carbohydrate to protein. This could be true, as the activities of the enzymes involved in transamination reactions (amino acids synthesis) use some of the glycolytic and TCA cycle intermediates such as phosphoglycerate, pyruvate, phosphoenolpyruvate and alpha ketglutarate as substrates in amino acids synthesis pathway. This agrees with the findings of Geo and Robert (2004), that raw material for amino acids synthesis can thus be obtained from glucose and the amino acids are synthesized at the cost of both energy (ATP) and reducing power (NADPH). One of such route is the enhanced activity of the enzyme phosphoenolpyruvate carboxylaze that converts phosphoenolpyruvate to oxaloacetate limiting the entrance of glycolytic intermediate into the tricarboxylic acid cycle (Lauaileche et al., 1996). This ascertion seems to concur with preliminary results of the amino acids content analysis of the unfermented and fermented Irish Potatoes with both wild type and mutant isolates (result not presented) indicating an increase but not significant $(\mathrm{P}>0.05)$ in the amino acids content of aspartic acids (synthesized from oxaloacetate) and glutamic acid ( synthesized from alfa ketoglutarate).

The absence of plasmid DNA in the Lactobacillus bulgaricus strain appeared to rule out possible involvement of extrachromosomal gene activity in protein (amino acids) synthesis. This could be tenable as Plasmids or extrachromosomal elements are known to contribute in the synthesis of some macromolecules, e.g. proteins (amino acids).

\section{REFERENCES}

Adams MR, Moss, MO. 1995. Food Microbiology. The Royal Society of Chemistry: Cambridge, UK; 398.

Axelsson L. 1998. Lactic Acid Bacteria: Classification and Physiology. In Lactic Acid Bacteria, Microbiology and Functional Aspects, Salminen S, Wright A (eds). Marcel Decker Inc.: New York, U.S.A.

Bruce PW, Brunswick NJ, Thomas JM, Edward LK, Hogan JD, Hartson WDC. 
1988. Food Biotechnology. A Scientific Status Summary by the institute of Food Technologists' Expert Panel on Food Safety and Nutrition, p. 133.

Elander RP. 1982. Traditional versus current approaches to genetic improvement of Microbial strains. In Over Production of Microbial Products, Krumphanzl V, Silkyta B, Vanek Z (eds). Academic Press: London; p. 353.

FAO SPOT Light. 1998. Small Scale Fermentation. Agriculture 21. http://www.fao.org/walcent FAY**** AGRICULT? Magazine/ 1981 25P3. Htm.

Frere J. 2008. Simple method for extracting plasmid DNA from lactic acid bacteria. Letters in Applied Microbiology, 18(4): 227-229.

Geoffrey MC, Robert EH. 2004. The Cell: A Molecular Approach ( $3^{\text {rd }}$ edn). ISBN 087893-214-3. Printed in USA; 76-78.

Hamilton Andy, Dave, 2004. Irish Potatoes (Solanum toberosum). http://www. Selfsufficient.Com/Potatoesshtm. Retrieved on 4 may, 2005.

Harrigan WF, McCance ME. 1993. Laboratory Method in Food and Dairy Micrbiology. Academic Press Inc.: San Diego; 213-219.

Kamal F, Samadi N, Assadi MM, Moazami N, Frazeli M. 2003. Mutagenesis of Lueconostoc mesenteroides and Selection of extransucrase Hyperproducing Strains. http://diglib.tums.ac.i.../kamal\%20

Article, $\% 20$ mutagenesis $\% 20$ of $\% 20 \%$ 20 edited 2003. Ht 12/29/04.

Louaileche HP, Bracqart C, Grimont G, Linden. 1996. Carbon dioxide fixation by cells and cell-free extracts of Strptococcus thermophilus. J. Diary Res., 63: 321-325.
Microbiologyprocedure.com Single Cell Protein. www.microbiologyprocedure. com/industrial-Microbiology/single....

Oxiod. 2004. MRS AGAR (De Mann, Ragosa, Sharpe). www. Oxiod.com

Ridge AG. 1982. A Rapid Method for Detection of Trichomonas vaginalis. Med. Lab. Sci., 39: 193-194.

Rowlands, RT, 1984. Industrial strain improvement: screens and genetic techniques. Enz. Microbial. Technol., 6: 290.

Sambrook J, Fritsch EF, Maniatis T. 1989. Molecular Cloning; a Laboratory Manual $\left(2^{\text {nd }}\right.$ edn). Cold Spring Harbor. Cold Spring Lab. Press: New York; 10291037.

Schieri EA, Blazevic DJ. 1981. Rapid identification of enterococci by reduction of litmus milk. J. Clin. Microbiol., 14: 227-228.

Shiio I. 1982. Metabolic regulation and overproduction of amino acids. In OcerProduction of Microbial Products, Krumphazll V, Sikyta B, Vanek Z (eds). Academic Press: London; 463.

South African Potatoes. 2005. Potatoes. http://www.Potatoes. Co. 29/Home. Asp?Pid $=621$.

Tserovska L, Stefanova S, Yordanova $\mathrm{T}$. 2002. Identification of lactic acid bacteria isolated from katyk, goat's milk and cheese. J. Cult. Coll., 3: 48-52.

Williams SK, Michael RC. 2000. Concept of Genetics $\left(6^{\text {th }}\right.$ edn). Prentice Hall, Inc.: upper saddle River New Jersey 07458; $470-474$. 